\title{
Marketing Strategies Education Oriented Market, Customers And Advantages Competitive
}

\author{
Elvi Rahmi' ${ }^{1}$ Moh. Zaini2 ${ }^{2}$ Moh. Muslim³, Imam Junaris ${ }^{4}$ \\ ${ }^{1}$ STIT Ahlussunnah Bukittinggi, Indonesia \\ ${ }^{2}$ UIN KH Achmad Siddiq Jember Jawa Timur, Indonesia \\ 3Unisma Jawa Timur, Indonesia \\ ${ }^{4}$ UIN Syayid Ali Rahmatullah Tulungagung Jawa Timur, Indonesia
}

Corresponding Author @ elvi.rahmi17@gmail.com

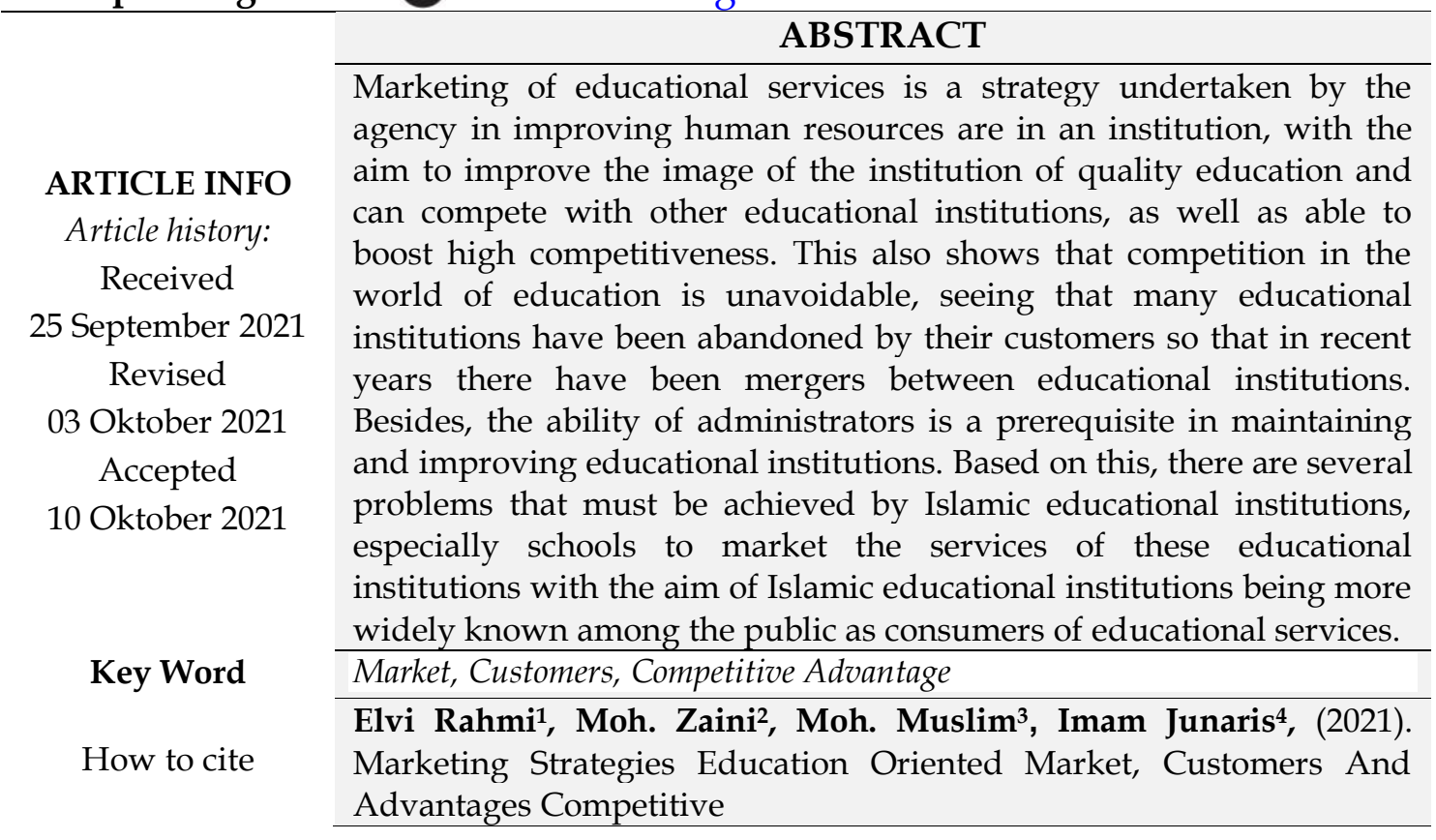

\section{INTRODUCTION}

Education is believed to be a strategic tool to improve human life. Through education, humans become intelligent, have the ability or skill, a good attitude to life, so that they can get along well in society. Education is an investment that provides social and personal benefits that make the nation dignified and its individuals become human beings with degrees. (Komariah \& Aan, 2015). The development of an educational institution to improve its image is determined by its capabilities through investment, service quality, and professionalism. This development focuses on the central problem of human resources which is formed through educational services. Not only companies that have to improve quality, but the world of education must also improve the quality of education so that consumers are more satisfied with educational services so that ultimately it produces good quality education. The development of science and technology requires society to make changes that 
are able to keep up with the times. Therefore, the role of knowledge is very important for the community in increasing their ability to follow competitive competition (Minarti, 2012).

Marketing for educational institutions is very necessary because competition between educational institutions is getting tighter, this can be seen from the many emerging various educational institutions that offer their respective advantages. Educational institutions as educational service providers need to be improved and must have initiatives in order to increase student customer satisfaction because every educational institution is required to have a strategy in marketing educational services in order to win the competition between educational institutions and to improve the image of the institution. In this era of globalization, educational institutions are understood as organizations that produce educational services and are purchased by consumers. The more expensive the cost of education, the consumers will demand that the quality of education is better and of higher quality. This concept is taken from theconcept marketing if consumers are not satisfied then the marketing will fail. Likewise with education if consumers are not satisfied then education is also considered a failure. Therefore, marketing in educational institutions is very important (David, 2012).

This marketing can be seen from the existence of various creative and innovative efforts by education providers to explore the uniqueness and advantages of their institutions so that they are increasingly needed and in demand by users of educational services. To attract prospective students, of course, a marketing strategy is needed that not only sells educational services as is, but how to approach them according to the wishes and satisfaction of consumers. So it can be said that an institution that wants to be successful for the future in the face of competition, must practice marketing continuously.

\section{RESEARCH METHODS}

This study uses aresearch type of libraryresearch, namely research whose data is obtained from literature studies or related literature, then analyzed theoretically-philosophically, concluded and raised by relevance and contextualization. The approach used is a phenomenological approach to see how market-oriented education marketing strategies, customers and competitive advantages can be managed properly so that the goals of Islamic education are achieved effectively and efficiently. 


\section{RESULT \& DISCUSSION}

\section{Market-Oriented Education Marketing Strategy, Customers and Competitive Advantage}

Strategy is defined as a careful plan of activities to achieve specific targets. Meanwhile, according to Bittel, strategy is a fundamental plan to achieve company goals. (Buchari, 2011) Strategy is seen as a program that includes goals to be achieved, and is accompanied by specific actions or steps to achieve these goals as an effort to respond to the environment. According to The American Marketing Association marketing is "Marketing is the planning and executing the conception, pricing, promotion and distribution of ideas, goods and services to create exchanges that satisfies individual and organizational goals". (Graham et al., 2008).

The definition above explains that marketing is a planning process to carry out the concept, price, promotion and distribution of a number of ideas, goods, and services to create exchanges that are able to satisfy individual and organizational goals. Kotler and Keller define: "Marketing is a societal process by which individuals and groups obtain what they need and want through creating, offering, and freely changing products and services of value with others". (Philip \& Keller, 2012).

Kotler's opinion reveals that marketing or marketing is not assumed in a narrow sense as sales but marketing has a very broad meaning. This is in accordance with George Brooker's opinion which states that the application of marketing is not only oriented to increasing the profit of the company or institution but how to create customer satisfaction as a form of responsibility to stakeholders for the quality of its output. The marketing concept is long-term oriented which emphasizes more on consumer satisfaction because marketing is an effort to satisfy consumers and fulfill the wishes of consumers to be satisfied with their products .

Thus, a marketing strategy is a plan that is systematically formulated regarding marketing activities which is used as a guide to achieve the goals that have been determined by an organization or educational institution. Meanwhile, competitiveness is efficiency and effectiveness that has the right target in determining the direction and results of the targets to be achieved which include the final goal and the final achievement process in facing competition. According to Sumihardjo, competitiveness includes: (1) the ability to strengthen its market position, (2) the ability to connect with its environment, (3) the ability to continuously improve performance, and (4) the ability to establish a profitable position. 
So competitiveness is the ability of a person or group to show superiority in certain respects, by showing the most favorable situations and conditions, better work results, faster or more meaningfully than others. Seeing the existing reality, there are still many institutions that are still focused on short-term marketing issues and use traditional approaches to implement marketing of educational services. Meanwhile, if it is related to the present, the implementation of marketing for educational services must use the concept of strategic management that focuses on long-term marketing issues and contemporary management approaches. Marketers of educational services must build a good perspective on the future of the institution, for that, of course, they must have a mindset that has a long-term and short-term view, so that they can prepare competent human resources and students to meet future institutions.

The concept of strategy has an important role in marketing. With the concept of marketing, an educational institution understands what the wants and needs of consumers are, so that an educational institution can bring up a product that is desired by the community (Umam, 2003). This marketing concept can be seen in the following chart:

Figure I : Marketing Concept The

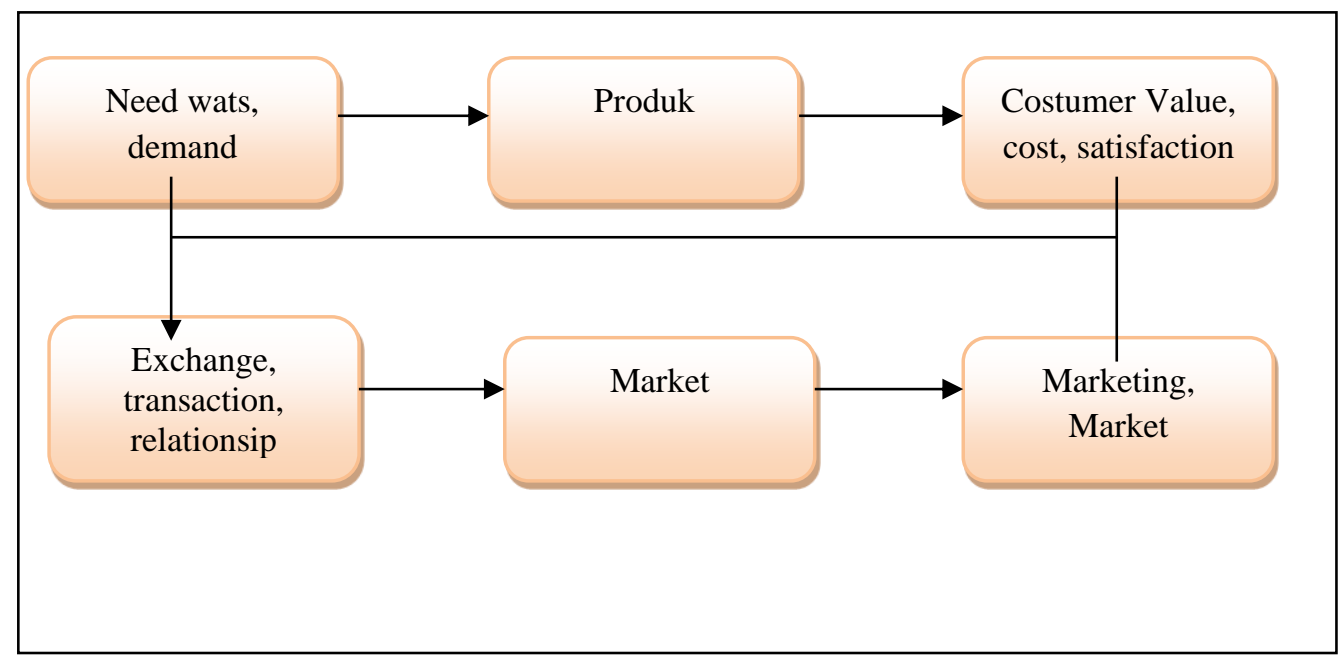

Chart above explains that the goal of marketing is to attract new customers by promising superior customer value, setting attractive prices, then distributing products easily, promoting effectively, and retaining existing customers while still adhering to the principle of customer satisfaction. So users of the marketing concept provide a logical rationale in achieving goals, in order to satisfy consumers by optimizing all the power and efforts of the institution.

The concept of Marketing in educational services is also developing from year to year. With the development of this concept, it will affect the 
implementation of marketing, including marketing in educational institutions. The development of the concept can be explained as follows :

\section{a. Production}

Concept This concept holds that the company makes as much production as possible. With this production will be obtained efficiency in the use of inputs and efficiency in the production process. If this is applied in educational services, it does not mean that educational institutions produce graduates en masse by ignoring quality, then lowering tuition fees, so that more interested people enter. However, the concept of production in educational services must continue to uphold the quality of its graduates, and the tuition fee is not too high.

b. Product

Concept This concept has been around for a long time, when manufacturers were in a strong position. Manufacturers produce very good products, according to the size of the producers themselves and not according to the wishes of consumers, with many consumers having very varied tastes. Consumer tastes cannot be identified with producer tastes. This is a mistake that occurs in the product concept, which equates the tastes of producers and consumers. As a result, if new creative competitors arise in the field of production, entrepreneurs who adhere to this product concept will lose in the competition. If this is applied in educational institutions, then the head of the institution may not act as he pleases, even in the context of wanting to improve quality. So that the task of a leader must monitor the will of consumers, the complaints discussed by human resources in the school environment.

c. Sales Concept

Entrepreneurs who adhere to theselling conceptargue that the important thing is that producers produce products, then the products are sold to the market using massive promotion. These producers have the belief that by way of promotion, consumers are influenced, stimulated, motivated to buy. If this is applied to educational institutions, then there is a tendency for institutions to use social media such as newspapers, TV, and placing advertisements to introduce the institution to the public.

d. Concept Marketing Concept marketing states that the manufacturer, do not just pay attention to themselves, but should see consumer tastes. This concept emphasizes more on customer satisfaction. The purpose of marketing thisis how the effort to satisfy the tastes, meet the "needs and wants" of consumers. The term needs is a need as a sense of deficiency in a person that must be met, 
while wants means a desire that is a need that has been influenced by various factors, such as education, beliefs, and so on. Educational institutions that adhere to this marketing concept understand exactly what they want to do. The task of educational institutions is not just a learning process in the classroom but must go further than that. Students must be satisfied with the institution's services, both in a teaching and learning atmosphere, clean classrooms, friendly teachers and so on.

e. The Community

Concept This concept states that the corporate world must be responsible to the community for all its business behavior. Likewise, educational institutions must be responsible for the public money collected and used, so that it provides maximum results for the benefit of the community.

The five marketing concepts can also be seen in the table below:

Table I: Development of Marketing

\begin{tabular}{|l|l|l|}
\hline \multicolumn{1}{|c|}{ Concepts } & \multicolumn{1}{|c|}{ Focused } & \multicolumn{1}{|c|}{ Assumptions } \\
\hline Production & $\begin{array}{l}\text { Emphasis on production costs and } \\
\text { increasing product availability Low }\end{array}$ & $\begin{array}{l}\text { prices and intensive } \\
\text { distribution are the main } \\
\text { considerations for } \\
\text { purchasing }\end{array}$ \\
\hline $\begin{array}{l}\text { Products } \\
\text { Product }\end{array}$ & Innovation & $\begin{array}{l}\text { Characteristics, } \\
\text { performance and quality } \\
\text { are considerations Main } \\
\text { for customers }\end{array}$ \\
\hline Sales & Increase in sales & $\begin{array}{l}\text { Sales and promotion } \\
\text { efforts must be more } \\
\text { active }\end{array}$ \\
\hline Marketing & $\begin{array}{l}\text { Customer satisfaction } \\
\text { Customer }\end{array}$ & $\begin{array}{l}\text { Purchases will be made if } \\
\text { customers get satisfaction } \\
\text { from community services }\end{array}$ \\
\hline community welfare & $\begin{array}{l}\text { Purchases will be made if } \\
\text { customers get satisfaction } \\
\text { from service }\end{array}$ \\
\hline
\end{tabular}

At development, marketing term is not only used byinstitutions profit alone, but is also used by organizations. non-profit The use of the term marketing 
has now developed in all sectors of human activity. This fact was expressed by Morris as quoted by Muhaimin, that today there is no organization, whether business or non-business that can be separated from marketing (marketing), the organization can choose to do it for the good of the organization or leave it for setbacks. So that education also uses the term marketing to market educational services. To form a good image of the institution, educational institutions develop various strategic efforts known as marketing mix strategies(Muhaimin, 2009).

Educational institutions try to carry outactivities marketing consumeroriented, so all staff personnel, both teachers and administrative staff must understand and live up to the mission of the institution. Theapproach marketing also demands to continuously strive to improve themselves and the services offered in providing quality services, so that stakeholders will continue to use the services that have been provided.

\section{Objectives and Functions of Market Oriented Educational Marketing, Customers and Competitive Advantage}

There are several objectives of educational marketing, namely: a) providing information to the public about the products of educational institutions, b) increasing public interest and interest in educational institution products, c) differentiating products of educational institutions with other educational institutions, d) giving more assessment to the community with the products offered, and e) stabilizing the existence and meaning of educational institutions in society. For this reason, it can be understood that what is to be achieved from educational marketing is to get customers who are on target, both in terms of quality and quantity of prospective customers.

While the function of education is as a renewal step when educational institutions must follow the current of globalization, competition in obtaining customers. Marketing functions(marketing)in education undertaken to create a good image of the school as an educational institution. The goal is to attract community members to use the educational services provided by the institution. The way to create this image of course depends on the targeted community members. So that ultimately educational marketing is useful as a step in balancing the position of education in the era of global competition.

Marketing Mix of Market Oriented Educational Services, Customers and Competitive Advantage

Education is a service provided by an institution, either in the form of services or in the form of nominal money. The function of the service itself in marketing is to form a good image of the institution and attract the interest of a number of prospective students. (Rambat \& Hamdani, 2006) According to 
Kotler service is "a service is any act or" performance that one party can offer to another that is basically intangible and does not result in the ownership of anything. Its production may or may not be tied to a physical product. This means that service is any action or performance offered by one party to another which in principle does not cause any transfer of ownership. The production can be related or not tied to a physical product (Philip \& Keller, 2012).

Service is basically an aspect of interaction between the consumer and the producer. Service is not an item, but an intangible process or activity. According to William J. Stanton, services are "services are those separately identifiable, essentially intangible activities that provide want- satisfaction, and that are not necessarily tied to the sale of a product or another service. To produce a service may or may not require the use of tangible goods. However, when such use is required, there is no transfer of the title (permanent ownership) to these tangible goods. This means that a service is something that is separately identifiable and intangible, offered to satisfy a need. Services can be produced by using tangible objects or not (Buchari, 2011).

Based on some of the definitions above, it can be concluded that education as a service product is something that is intangible but can meet the needs of consumers who are processed by using or not using the help of physical products where the process that occurs is an interaction between service providers and service users which has the nature of not resulting in transfer of rights or ownership. Thus, the components of educational institutions must always keep up to date on the quality and competence side.

The main objective of this process is to improve the quality of education on an ongoing basis, and continuously so as to produce quality human resources. These services have eight characteristics, namely: 1) services cannot be stored and consumed when they are produced, 2) services depend on time, 3) services depend on place, 4) consumers are an integral part of the service production process, 5) every person or anything related to consumers has a role in providing a role, 6) changes to the concept of benefit, 7) liaison employees are part of the service production process, 8) service quality cannot be improved during the production process because service production occurs in real time (Fandy, 2014).

In addition, services also have four main characteristics that greatly affect the design of marketing programs, namely: 1) Intangibility (intangible). This means that services cannot be seen, tasted, smelled, heard, or touched before they are bought or consumed, 2) inseparabilityinseparable (). Services cannot be separated from the source, namely the company that produces them, 3) variability (varies). The services provided often change depending on who 
provides them, when and where the presentation of the services is carried out, and 4) perishability (easy to destroy).services Perishability cannot be stored or easily destroyed so they cannot be sold in the future (Mudie \& Pirrie, 2006).

In relation to education, services can be defined as the activities of educational institutions providing services or delivering educational services to consumers in a satisfactory manner.

Marketing in the context of educational services is a social and managerial process of getting what is needed and wanted through creating offers, exchanging products of value with other parties in the field of education. Marketing ethics in education is to offer quality intellectual services and overall character building. This is because education is more complex, which is carried out with full responsibility, so that the results of education will refer far into the future, fostering the lives of citizens, the next generation of scientists in the future (Buchari, 2011).

The marketing mix of educational services in question can be seen from the 7P concept, namely: Product (Product), Price (Price), Place (Location or Place), Promotion (Promotion), Person (People or Human Resources), Physical Evidence (Facilities or Physical Facilities) and Process (Process). So the 7Ps of the education services marketing mix strategy above influence each other, so they are all important as a unified strategy, namely the mix strategy. In addition, this marketing mix strategy serves as a guide in using marketing elements that can be controlled by organizational leaders, to achieve organizational goals in the field of marketing.

\section{Application of Marketing in Education}

The application of marketing in education aims to bring services closer to the wishes and satisfaction of students, which of course aims to increase the resources and quality of graduates in an educational institution. According to (Wibowo, 2006) the steps taken in the application are as follows:

a. Planning (Planning). Planning is the first step that must be done by a manager. Thefunction planning includes organizational goals, developing overall strategies to achieve goals, developing and coordinating activities to achieve expected goals. Planning in educational marketing aims to reduce or compensate for uncertainty and upcoming changes, focus attention on goals, ensure or get the process of achieving goals carried out efficiently and effectively, and facilitate control.

b. Organizing (Organizing). Organizing is the responsibility of the manager to design the organizational structure and organize the division of labor. This includes considering what tasks are to be done, 
who performs them, how tasks are grouped, who reports to whom and where decisions are made. So, in this organization, a clear structure is needed as a process of dividing work into more detailed tasks, and assigning tasks according to the capabilities of each existing HR and coordinating them in order to effectively achieve organizational goals.

c. Actuating (Movement). Actuating with respect to the manager's function to carry out actions and carry out the work that is treated to achieve the goals to be achieved by the organization. Actuating is the implementation of what is planned in thefunction planning by utilizing the preparations that have been made in organizing. Regarding the implementation of this marketing, planning a good strategy requires an initial step towards successful marketing. In this case, of course, marketing implementation is carried out through a process that changes strategies and plans into marketing actions in order to achieve strategic marketing goals.

d. Controlling (Controlling). Controlling an activity to ensure that everything works as it should and monitor the performance of the organization. The supervisory system may consist of a supervisory mechanism from the leader related to the completion of delegated tasks. Conformity between task completion and task planning. Good oversight is oversight that has been built in when compiling a program. In compiling the program, there must be an element of control in it. The goal is for someone who does a job to feel that his job is cared for by his superiors, not a job that is ignored or taken lightly. Therefore, the best supervision is supervision that is built from within the person being supervised and from a good supervision system (Muhaimin, 2009).

To achieve good control, madrasas need information that is sufficiently accurate and adequate. The information that has been obtained is used as a reference in the implementation of control and evaluation. According to (Didin \& Tanjung, 2003) there are three types of marketing controls that can be used by madrasas, namely:

a) Annual control plans, which include monitoring on ongoing marketing performance to ensure that the annual sales volume and targeted profits are achieved.

b) Profitability control, consists of determining the actual profitability of the marketing that has been carried out, such as the suitability of existing services with existing needs in society, market segments, promotional channels and so on. 
c) Marketing audit, which aims to analyze marketing objectives, strategies and optimally adapted systems and the predicted environment of marketing objectives.

The implementation of this control system is an action to correct performance, both in the short and long term. However, regular control and evaluation must be carried out so that mistakes made by the institution can be corrected directly and further anticipation can be made quickly for the development of the institution.

\section{CONCLUSION}

To improve the existence and image of educational institutions, education managers should apply the concept of a marketing strategy for educational services. This is because the marketing of educational services is a step to reform educational institutions in order to market educational service products to the public by creating and offering service product innovations that are in line with market expectations and demands.

The objectives of marketing in education are: a) providing information to the public about the products of educational institutions, b) increasing public interest and interest in the products of educational institutions, c) differentiating the products of educational institutions from other educational institutions, d) providing more assessments to the public. with the products offered, and e) stabilize the existence and meaning of educational institutions in society.

In formulating this marketing strategy, education managers should also pay attention to what the expectations and needs of students are by analyzing complaints from students and finding solutions that can improve these complaints, so that ultimately the institution can achieve a balance in operationalizing market segments and can achieve goals in accordance with the mission of the institution.

\section{REFERENCE}

Buchari, A. (2011). Marketing Management and Marketing Services. Alfabeta.

David, W. (2012). Marketing of Educational Services. Salemba Empat.

Didin, H., \& Tanjung, H. (2003). Sharia Management in Practice. Gema Insani.

Fandy, T. (2014). Service Marketing. Andi Publisher.

Graham, J. H., Piercy, N. F., \& Nicolaud, B. (2008). Marketing Strategy and Competitive Positioning. Prentice Hall Inc.

Komariah, \& Aan, E. (2015). Administrasi Pendidikan. Alfabeta.

Minarti, S. (2012). School Management: Managing Educational Institutions Independently. Ar Ruzz Media. 
Journal of Education and Teaching Learning (JETL)

Volume 3, No 3, September 2021

Page 29-40

Mudie, P., \& Pirrie, A. (2006). Service Marketing Management. Elseivier.

Muhaimin. (2009). Reconstruction of Islamic Education. Rajawali Pers.

Philip, K., \& Keller, K. L. (2012). Marketing Management. Prentice Hall.

Rambat, L., \& Hamdani, A. (2006). Service Marketing Management. Salemba Empat.

Umam, K. (2003). Islamic Banking Management. CV Pustaka Setia.

Wibowo. (2006). Manajemen Perubahan. Raja Grafindo Persada. 